Agata Skrzat-Klapaczyńska*1,2, Bartłomiej Matłosz ${ }^{3}$, Dan Otelea ${ }^{4}$, Arjan Harxhi ${ }^{5}$, Anna Vassilenko ${ }^{6}$, Natalia Bolokadze ${ }^{7}$, Kristi Rüütel ${ }^{8}$, Antonios Papadopoulos ${ }^{9}$, Mariana Mardarescu ${ }^{10}$, Mike Youle ${ }^{11}$, Justyna D. Kowalska ${ }^{1,2}$ and Andrzej Horban ${ }^{1,2}$

\title{
EPIDEMIOLOGICAL CHARACTERISTICS AND ACCESS TO END-STAGE LIVER DISEASE CARE FOR HIV-POSITIVE PATIENTS WITH HCV AND/OR HBV COINFECTIONS IN CENTRAL/EASTERN EUROPEAN AND NEIGHBORING COUNTRIES - DATA FROM THE ECEE NETWORK
}

\author{
CHARAKTERYSTYKA EPIDEMIOLOGICZNA I DOSTEP DO OPIEKI \\ W SCHYŁKOWEJ NIEWYDOLNOŚCI WĄTROBY U PACJENTÓW ZAKAŻONYCH \\ HIV WSPÓŁZAKAŻONYCH HCV I/LUB HBV W KRAJACH EUROPY ŚRODKOWEJ/ \\ WSCHODNIEJ ORAZ W KRAJACH SĄSIEDNICH - DANE GRUPY ECEE
}

\author{
${ }^{1}$ Hospital for Infectious Diseases, Warsaw, \\ ${ }^{2}$ Medical University of Warsaw, Department for Adult's Infectious Diseases, Warsaw, Poland \\ ${ }^{3}$ Hospital for Infectious Diseases, HIV Out-Patient Clinic, Warsaw, Poland, \\ ${ }^{4}$ National Institute for Infectious Diseases, Bucharest, Romania \\ ${ }^{5}$ Department of Infectious Disease, Faculty of Medicine, University Hospital Center of Tirana, Albania \\ ${ }^{6}$ Belarusian State Medical University, Minsk, Belarus \\ ${ }^{7}$ Infectious Diseases, AIDS and Clinical Immunology Research Center, Tbilisi, Georgia \\ ${ }^{8}$ Department of Drug and Infectious Diseases Epidemiology, Tallinn, Estonia \\ ${ }^{9}$ Medical School - National and Kapodistrian University of Athens, \\ University General Hospital "ATTIKON", Athens, Greece \\ ${ }^{10}$ Pediatric Department, National Institute for Infectious Diseases "Prof Dr Matei Balş", Bucharest, Romania \\ ${ }^{11}$ Department of HIV Medicine, Royal Free London Hospital, London, UK
}

\section{ABSTRACT}

OBJECTIVES. There is currently an urgent need to harmonize hepatitis standards of care for HIV-positive patients across Europe. The HIV epidemic in Central and Eastern Europe has often been driven by injecting drug use, therefore a higher rate of co-infection with $\mathrm{HCV}$ and $\mathrm{HBV}$ is expected in this region. We have investigated the epidemiological prevalence and treatment availability for end-stage liver disease in $\mathrm{HIV} / \mathrm{HCV} / \mathrm{HBV}$ coinfections in countries represented in the ECEE Network Group.

METHODS. The Euroguidelines in Central and Eastern Europe (ECEE) Network Group was initiated in February 2016 to compare standards of care regarding HIV infection in the region. Information about HIV/HCV/HBV co-infections and the availability for end-stage liver disease treatment for HIV-positive patients were collected through on-line surveys. The respondents were ECEE members from 16 countries of the region. The information on co-infection prevalence was sourced from WHO, national HIV programmes, articles published in international journals, single clinic reports, and personal information in ten of the participating countries $(62.5 \%)$.

RESULTS. The HIV/HCV co-infection rate was from 3\% to $99 \%$. The range of reported of HIV/HBV coinfection percentages was $2.3 \%$ to $40 \%$. HIV/HCV/HBV co-infection ranged from $0 \%$ to $9 \%$.

Regarding treatment for end-stage liver disease, liver transplantation was an available option for HIV-positive patients in only three countries $(19 \%)$.

CONCLUSION. Our findings revealed only a limited number of treatment options for the end-stage liver disease in HIV-positive patients for the vast majority of Central and Eastern European countries. There are gaps in epidemiological surveillance in this region. It appears there are many differences in the number of co-infected patients among Central and Eastern European and neighboring countries, but there is no unification of information sources.

Key words: $H I V, H C V, H B V$, end-stage liver disease

(c) National Institute of Public Health - National Institute of Hygiene / Narodowy Instytut Zdrowia Publicznego - Państwowy Zakład Higieny 


\section{STRESZCZENIE}

CELE. Istnieje pilna potrzeba ujednolicenia standardów opieki nad pacjentami zakażonymi wirusem HIV w całej Europie. Epidemia HIV w Europie Środkowej i Wschodniej często była spowodowana dożylną podażą narkotyków, dlatego w tym regionie stwierdza się większą liczbę koinfekcji z HCV i HBV. Zbadaliśmy epidemiologiczne rozpowszechnienie i dostępność leczenia w końcowym stadium choroby wątroby w koinfekcjach HIV / HCV / HBV w krajach reprezentowanych w Grupie ECEE.

METODY. Grupa ECEE (Euroguidelines in Central and Eastern Europe) została stworzona w lutym 2016 roku w celu porównania standardów opieki nad zakażeniem HIV w tym regionie. Informacje na temat koinfekcji HIV / HCV / HBV i dostępności leczenia końcowego stadium choroby wątroby u pacjentów zakażonych wirusem HIV zebrano za pomocą ankiet on-line. Respondentami byli członkowie ECEE z 16 krajów regionu. Źródłem informacji na temat rozpowszechnienia koinfekcji były: WHO, krajowe programy dotyczące HIV, artykuły publikowane w międzynarodowych czasopismach, pojedyncze raporty klinik i informacje personalne w dziesięciu (62,5\%) krajach.

WYNIKI. Częstość występowania koinfekcji HIV / HCV wynosiła od 3\% do 99\%. Częstość występowania koinfekcji HIV / HBV wynosiła od 2,3\% do 40\%. Koinfekcja HCV / HBV i HIV występowała w zakresie od 0\% do 9\%. Jeśli chodzi o leczenie schyłkowej choroby wątroby, tylko w trzech (19\%) krajach transplantacja wątroby była dostępną opcją dla pacjentów zakażonych HIV.

WNIOSKI. Nasze wyniki wykazały ograniczoną liczbę opcji leczenia końcowego stadium choroby wątroby u pacjentów zakażonych HIV w większości krajów Europy Środkowej i Wschodniej. W tym regionie występują luki w nadzorze epidemiologicznym. Wydaje się, że istnieje wiele różnic w liczbie pacjentów z koinfekcjami w Europie Środkowej / Wschodniej i krajach sąsiednich, ale nie ma ujednoliconych źródeł informacji.

Slowa kluczowe: $H I V, H C V, H B V$, schyłkowa niewydolność wątroby

\section{INTRODUCTION}

$\mathrm{HCV}$ and HBV infections are more common in HIV-infected patients than in the general population. It is estimated that $\mathrm{HCV}$ infection occurs in 10 million HIV-positive patients, roughly corresponding to one in three HIV-infected patients; whereas HBV infection has been reported as being less common and is found in 3-5 million HIV-positive patients (1).

It is well documented that co-infections of HBV$\mathrm{HIV}$ and HCV-HIV lead to a more rapid progression to liver cirrhosis than HBV or HCV mono-infections (2). Currently, the life expectancy of HIV-infected people is close to that of uninfected people (3). Consequently, we observe disease progression of chronic hepatitis, and especially end-stage liver disease (ESLD), more frequently in these patients (4). ESLD and hepatocellular carcinoma have become leading causes of morbidity and mortality in HBV-HIV, HCV-HIV, and $\mathrm{HBV} / \mathrm{HCV} / \mathrm{HIV}$-infected patients (5). At the same time it has been well documented that successful treatment of $\mathrm{HCV}$ is associated with a decrease in the incidence of liver disease and liver-related death, as well as co-morbidities such as diabetes mellitus (6). However, a worrying findings in a pan-European study has recently been reported, namely, a lower uptake of HCV DAA therapy in Eastern European countries (7).

The HIV epidemic in Central and Eastern Europe has often been driven by injecting drug use, and therefore, a higher rate of co-infection with $\mathrm{HCV}$ and $\mathrm{HBV}$ is expected and/or registered in this region (8).
Unfortunately, there is no accurate data on the number of HIV-infected patients who are also infected with $\mathrm{HBV} / \mathrm{HCV}$ in Central and Eastern European Countries. There is currently an urgent need to harmonize hepatitis care for HIV-positive patients across Europe (9).

We have investigated the prevalence of coinfections among HIV infected patients and treatment availability for end-stage liver disease in $\mathrm{HIV} / \mathrm{HCV} / \mathrm{HBV}$ coinfections in countries represented in the ECEE Network Group.

\section{METHODS}

The Euroguidelines in Central and Eastern Europe (ECEE) Network Group was initiated in February 2016 to compare and improve standards of care for HIV infection in the region. Information about $\mathrm{HIV} / \mathrm{HCV} /$ HBV co-infections and the availability of treatment for the end-stage liver disease in HIV-positive patients was collected through on-line surveys. The respondents were ECEE members from 16 countries from within the region (Bulgaria, Bosnia and Herzegovina, Estonia, Armenia, Greece, Republic of Moldova, Romania, Poland, Slovenia, Croatia, Albania, Hungary, Turkey, Ukraine, Serbia, and Georgia). The online survey included questions about the estimated number of patients infected with $\mathrm{HIV} / \mathrm{HBV}, \mathrm{HIV} / \mathrm{HCV}$, and HIV/ $\mathrm{HBV} / \mathrm{HCV}$. The respondents were asked to indicate a specific source for this information. In addition, there was a question about the availability of ESLD treatment (Table 1). 
Table 1. On-line survey questions

Tabela 1. Pytania w ankiecie on-line

\begin{tabular}{|c|}
\hline 1. What is your country? \\
\hline 2. What is your current occupation? \\
\hline $\begin{array}{l}\text { 3. What is the number of HCV-infected persons in your country? (please provide the source of information and if this } \\
\text { number is "diagnosed" or "estimated"). }\end{array}$ \\
\hline 4. Which group is dominant among HCV-positive persons? \\
\hline 5. Which groups are routinely tested in the public healthcare system for HCV infection (anti-HCV antibodies)? \\
\hline 6. Do you have access to routine HCV RNA testing? \\
\hline 7. Do you have access to routine HCV genotyping? \\
\hline 8. Do you have access to routine HCV resistance testing? \\
\hline 9. Describe the antiviral treatments available for HCV infection in the public healthcare system (free of charge). \\
\hline 10. Do you have DAA drugs available in your country infection in public healthcare (free of charge)? \\
\hline $\begin{array}{l}\text { 11. What is the number of HBV infected persons in your country? (please provide the source of information and if this } \\
\text { number is "diagnosed" or "estimated"). }\end{array}$ \\
\hline 12. Which group is dominant among HBV-positive persons? \\
\hline 13. Which groups are routinely tested in the public healthcare system? \\
\hline 14. Do you have access to routine HBV DNA testing? \\
\hline 15. Do you have access to routine HBV genotyping? \\
\hline 16. Which antiviral treatment is available for HBV infections in the public healthcare system? \\
\hline 17. Describe the availability of end-stage liver disease treatment in the public healthcare system. \\
\hline $\begin{array}{l}\text { 18. What is the estimated number/percent of HIV-positive patients co-infected with HCV in your country? (please } \\
\text { provide the source of information, or write "estimated," or write "unknown" if it is not possible to estimate) }\end{array}$ \\
\hline $\begin{array}{l}\text { 19. What is the estimated number/percent of HIV-positive patients co-infected with HBV inyour country? (please provide } \\
\text { the source of information, or write "estimated," or write "unknown" if it is not possible to estimate) }\end{array}$ \\
\hline $\begin{array}{l}\text { 20. What is the estimated number/percent of HIV-positive patients co-infected with both HCV and HBV in your country? } \\
\text { (please provide the source of information, or write "estimated," or write "unknown" if it is not possible to estimate) }\end{array}$ \\
\hline
\end{tabular}

\section{RESULTS}

Sixteen countries participated in the survey, with participants limited to one person from each country. The information on coinfection prevalence was sourced from WHO, national HIV programs, articles published in international peer-reviewed journals, single clinic reports, and personal information in ten of the participating countries $(62.5 \%)$. The sources of the data were not available for six countries $(37.5 \%)$, and in these cases personal communication (based on regional/local hospital data) was used instead (Table $2)$. The results of the survey are shown in Table 2. The HIV/HCV co-infection rate among HIV infected individuals was from $3 \%$ to $99 \%$. According to the available data, the highest proportion of $\mathrm{HIV} / \mathrm{HCV}$ coinfection was reported in Estonia (95-99\%). The range of reported $\mathrm{HIV} / \mathrm{HBV}$ co-infection percentages was from $2.3 \%$ to $40 \%$ referring to HIV infected patients. The highest percentage of HIV/HBV co-infection was recorded in Romania (10-40\%). HIV/HCV/HBV coinfection ranged from $0 \%$ to $9 \%$. According to the available data, Romania is the country with the highest seroprevalence of HCV/HBV/HIV co-infection (9\%) (Table 2).
Liver transplantation for end-stage liver disease was an available option for HIV-positive patients only in three countries (19\%), namely, Bosnia and Herzegovina, Greece, and Poland. At the same time, liver transplantation for HIV-negative patients was possible in nine countries (56\%): Bulgaria, Estonia, the Republic of Moldova, Romania, Slovenia, Croatia, Hungary, Turkey, and Serbia. In four countries (25\%) - Albania, Ukraine, Armenia, and Georgia - there were no procedures available for ESLD. (Table 3).

\section{DISCUSSION}

In our study, $\mathrm{HIV} / \mathrm{HCV}$ co-infection rates ranged from 3\% to as high as $99 \%$ of HIV-positive individuals. The highest reported rate was in Estonia, where the main mode of HIV infection is injecting psychoactive substances use. The highest proportion of $\mathrm{HIV} / \mathrm{HBV}$ and $\mathrm{HIV} / \mathrm{HCV} / \mathrm{HBV}$ were reported in Romania (10-40\% and $9 \%$ respectively) in our study. At the same time, our data underlines that access to end-stage liver disease treatment for HIVpositive patients is very poor: only three countries had liver transplantation as an available option for HIV-positive patients. 
Table 2. Estimated number (N) or percent (\%) of co-infection referred to HIV-positive patients in each country's population. Results from the on-line survey.

Tabela 2. Koinfekcje HIV i wirusowe zapalenie wątroby - wyniki ankiety on-line

\begin{tabular}{|c|c|c|c|c|}
\hline Country & $\begin{array}{l}\text { HIV/HCV } \\
\text { estimated } \\
\text { number }(\mathbf{N}) \text { or } \\
\text { percent(\%) }\end{array}$ & $\begin{array}{l}\text { HIV/HBV } \\
\text { N or } \%\end{array}$ & $\begin{array}{l}\mathrm{HIV} / \mathrm{HCV} / \mathrm{HBV} \\
\quad \mathrm{N} \text { or } \%\end{array}$ & Source of information \\
\hline Bulgaria & $25.6 \%$ & $10.4 \%$ & $3.3 \%$ & (38) \\
\hline Bosnia and Hercegovina & $6 \%$ & $4 \%$ & none & $\begin{array}{l}\text { Personal communication (Velida Mulab- } \\
\text { dic) Unpublished data from the Clinic for } \\
\text { Infectious Disease in Sarajevo. }\end{array}$ \\
\hline Estonia & 95-99\% & $4-5 \%$ & $4.5 \%$ & (39) \\
\hline Armenia & $13.9 \%$ & $2.3 \%$ & $0.24 \%$ & $\begin{array}{l}\text { Personal communication } \\
\text { (Tatevik Balayan, National Center for } \\
\text { Disease Control and Prevention, Yere- } \\
\text { van, Armenia). }\end{array}$ \\
\hline Greece & $12.8 \%$ & $3-6 \%$ & $0.09 \%$ & $(4,40)$ \\
\hline Republic of Moldova & $16.5 \%$ & $6.4 \%$ & $5 \%$ & (41) \\
\hline Romania & $20 \%$ & $10-40 \%$ & $9 \%$ & $(42)$ \\
\hline Poland & $33 \%$ & $15 \%$ & $7 \%$ & $\begin{array}{l}\text { Personal communication } \\
\text { (Karolina Pyziak-Kowalska; Hospital } \\
\text { for Infectious Diseases, Warsaw). }\end{array}$ \\
\hline Slovenia & $5.7 \%$ & $4 \%$ & unknown & (43) \\
\hline Croatia & $39(\mathrm{~N})$ & $4 \%$ & $<1 \%$ & $\begin{array}{l}\text { Personal communication } \\
\text { (Josip Begovac, University of Zagreb } \\
\text { School of Medicine, University Hospital } \\
\text { of Infectious Diseases, Zagreb, Croatia). }\end{array}$ \\
\hline Albania & $3-5 \%$ & $17-20 \%$ & $1.5-2 \%$ & $\begin{array}{l}\text { Infectious Disease Service, University } \\
\text { Hospital center of Tirana (Arjan Harxi). }\end{array}$ \\
\hline Hungary & $\begin{array}{l}100(\mathrm{~N}) \text { per } 2,000 \\
\text { HIV-positive }\end{array}$ & $\begin{array}{l}70(\mathrm{~N}) \text { per } \\
2,000 \mathrm{HIV}- \\
\text { positive }\end{array}$ & $\begin{array}{l}10(\mathrm{~N}) \text { per } \\
\text { 2,000 HIV-positive }\end{array}$ & $\begin{array}{l}\text { National HIV Center } \\
\text { (Botond Lakatos, Saint Laszlo Hospital } \\
\text { National Center of HIV, Semmelweis } \\
\text { University Faculty of Infectious Dis- } \\
\text { eases, Budapest, Hungary). }\end{array}$ \\
\hline Turkey & $2,000(\mathrm{~N})$ & $6,000(\mathrm{~N})$ & $1,000(\mathrm{~N})$ & $\begin{array}{l}\text { Personal communication } \\
\text { (Tansu Yamazhan, Ege University fac- } \\
\text { ulty of Medicine Department of Infec- } \\
\text { tious Diseases and Clinical Microbiol- } \\
\text { ogy Bornova Izmir, Turkey). }\end{array}$ \\
\hline Ukraine & unknown & unknown & unknown & $\begin{array}{l}\text { Personal communication } \\
\text { (Marta Vasylyev, Lviv Regional AIDS } \\
\text { Center, Lviv, Ukraine). }\end{array}$ \\
\hline Serbia & $25 \%$ & $4.5 \%$ & $1.7 \%$ & $\begin{array}{l}\text { PhD student of Dr. Jovan Ranin, } \\
\text { Infectiologist, HIV clinician. }\end{array}$ \\
\hline Georgia & $34 \%$ & unknown & $1.9 \%$ & $\begin{array}{l}\text { Personal communication } \\
\text { (Nikoloz Chkhartishili, Infectious Dis- } \\
\text { eases, AIDS and Clinical Immunology } \\
\text { Research Center, Tbilisi, Georgia). }\end{array}$ \\
\hline
\end{tabular}

Our results show huge disparities in the epidemic across a relatively small geographical region, and underlines the need for an individualized approach to $\mathrm{HCV}$ elimination. Our data correlates well with estimates from global reports. In a systematic review and meta-analysis published in 2016, Platt et al. analyzed the general prevalence of $\mathrm{HIV} / \mathrm{HCV}$ coinfections among HIV-positive patients, and obtained a result of $6.2 \%$ (10). They found a total of around 2,278,400 HIV/HCV co-infections worldwide. Of these people $1,362,700$ were injecting drug users (IDU), which means that IDU patients had the highest risk of $\mathrm{HIV} / \mathrm{HCV}$ co-infection. Vickerman et al published data about the $90 \%$ prevalence of $\mathrm{HIV} / \mathrm{HCV}$ co-infection among HIV-infected IDUs across 43 countries (11). Soriano et al published data about the HIV/HCV epidemic in Russia and Ukraine (12). The prevalence of co-infection in these countries was $70 \%$, 
and was connected with the most common route of infection - injecting drug use. In contrast, in Western Europe countries, the prevalence of $\mathrm{HIV} / \mathrm{HCV}$ coinfection is estimated to be $10-15 \%$ (13). This is due to the different routes of HIV/HCV transmission. In Western European countries men who have sex with men (MSM) is the dominant population having HIV/ HCV-infected individuals (13).

Table 3. Availability of end-stage liver disease treatment for patients in Central and Eastern Europe

Tabela 3. Dostępność leczenia schyłkowej choroby wątroby u pacjentów z HIV w Europie Środkowej i Wschodniej

\begin{tabular}{|c|c|c|}
\hline Country & $\begin{array}{c}\text { Liver } \\
\text { transplantation } \\
\text { for HIV- } \\
\text { negative }\end{array}$ & $\begin{array}{c}\text { Liver } \\
\text { transplantation } \\
\text { for HIV- } \\
\text { positive }\end{array}$ \\
\hline Bulgaria & Yes & No \\
\hline $\begin{array}{c}\text { Bosnia and } \\
\text { Hercegovina }\end{array}$ & Yes & Yes \\
\hline Estonia & Yes & No \\
\hline Armenia & No & Yes \\
\hline Greece & Yes & No \\
\hline Republic of Moldova & Yes & No \\
\hline Romania & Yes & Yes \\
\hline Poland & Yes & No \\
\hline Slovenia & Yes & No \\
\hline Croatia & Yes & No \\
\hline Albania & No & No \\
\hline Hungary & Yes & No \\
\hline Turkey & Yes & No \\
\hline Ukraine & No & Yes \\
\hline Serbia & No & No \\
\hline Georgia & & \\
\hline & & \\
\hline
\end{tabular}

Regional data may differ significantly from global data due to epidemiological differences in specific populations and the most common routes of HIV infection. In the USA, Soriano et al (14) estimated that about $30 \%$ of HIV-positive patients had HCV coinfections. On the other hand, two regional metaanalyses in South Africa $(15,16)$ documented that $\mathrm{HIV} / \mathrm{HCV}$ co-infections were $7 \%$ and $5.7 \%$ among HIV-positive individuals. Numbers of HIV/HCV-coinfected patients were estimated to be higher in China with the overall prevalence being $41.8 \%$ (17). It is probable that the number of $\mathrm{HIV} / \mathrm{HCV}$ co-infections will decrease in Central and Eastern European countries due to the wide availability of antiviral drugs (18).
The range of reported HIV/HBV co-infection percentages was from $2.3 \%$ to $40 \%$ in our study. It is estimated that globally, $10 \%$ of the HIV population is HBV-co-infected (19). The prevalence of HBV varies depending on the geographical region (20). In the endemic regions of Asia most HBV infections are acquired by children under five years of age, which results in chronic infections. Feng et al published Chinese data in which the prevalence of HBV and HIV co-infection was $13.85 \%$ (21). Similar results were found in Africa (22). On the other hand, in Europe and United States the majority of HBV/HIV co-infections occur in the MSM population (23).

In our study, HIV/HCV/HBV co-infection ranged from $0 \%$ to $9 \%$. Owing to shared routes of transmission, $\mathrm{HIV} / \mathrm{HCV} / \mathrm{HBV}$ triple infections usually occur in IDUs (24). However, the prevalence of $\mathrm{HIV} / \mathrm{HCV} /$ HBV infections is low as evidenced by the results in individual scientific publications. In USA, $\mathrm{HBV} / \mathrm{HCV}$ co-infections were detected in $1.58 \%$ of HIV-positive patients (25), but in a Spanish cohort the prevalence of multiple hepatitis was $4.7 \%$ (26). In Chinese prevalence studies, HIV/HCV/HBV triple infections were estimated to be $6.9 \%, 6.0 \%$, and $8.5 \%$ in plasma donors, blood recipients, and IDUs respectively (27).

Non-AIDS-related conditions account for an increasing proportion of HIV-infected patients' death, with liver and kidney failure causing death in an estimated $10 \%$ of patients (28).Transplantation as a treatment option for HIV-positive patients emerged in 1990s, and nowadays is available in many Western countries for these patients. A report from the University of California, San Francisco in 2003, described a cohort study of 14 HIV-positive patients who received either a kidney or liver transplant (29). For the four liver transplant recipients, patient and graft survival was $75 \%$ at 380 days. The single death in the liver transplant group was caused by recurrence of HCV. Over the last years, several studies have confirmed that HIV-positive recipients have liver graft and patient survival rates similar to HIV-negative recipients, with the exception of recipients who are coinfected with HIV and HCV (30-32). But even in coinfected patients, especially taking into consideration the lack of other treatment options, results seem to justify referring these patients for transplantation. Additionally, with increasing expertise and new treatment options we are now able to identify several modifiable donor/recipient risk factors that could be changed in order to improve survival in HIV/HCV-coinfected patients (32).

Our findings revealed a lack of treatment options for ESLD in HIV-positive patients for the vast majority of Central and Eastern European countries. Among the sixteen countries only one in five had liver 
transplantation as an available option for HIV-positive patients as a treatment for end-stage liver disease. This may underestimate access to transplantation, as, at least in some countries, despite the lack of a systemic solution, HIV-positive patients can receive solid organ transplants (33). While in some regions this might reflect poor access to transplantation medicine in general (34). Another possible limitation on liver transplantation might be low numbers of donors.

As mentioned above patient and graft survival is comparable in HIV-negative and HIV-positive recipients. It seems that nowadays there is no reason to deny access to liver transplantation for HIV-infected individuals who meet the established criteria (32). Still, there is the serious and worldwide issue of organ shortage for transplantation. In the past, using organs from HIV-positive donors has been avoided because of concerns about HIV superinfection and transmitted drug resistance; although, in clinical studies the survival rates are similar to those of HIV-positive recipients who obtain organs from HIV-negative and HIV-positive donors $(32,35,36)$. In the United States, the use of HIV-positive donor organs was legalized in 2013, but only in the setting of an approved research protocol (37). This may prove helpful in the future, especially in countries with high numbers of infected individuals, although such opportunities have still not been well explored in Europe. All these factors which limit access to transplantation, as well as the inferior survival of HCV-co-infected patients, indicate that resource limited countries should be targeted with programs for wide access to hepatitis treatment in order to prevent mortality.

Despite good survival rates, treatment of HIVpositive transplant recipients remains an ongoing challenge and requires a highly experienced and multidisciplinary team. Some recommendations state: "avoid liver transplantation in centers with a low volume of liver transplantation in HIV-infected patients and no well-organized multidisciplinary team" (32). This may be a serious obstacle for centers with small numbers of transplants per year. In such a setting access to transplantation may be restricted for HIVpositive patients.

Antirejection treatment after transplantation requires a high level of compliance. When the proportion of injecting drug users among the HIVinfected population is high, as it is in some Eastern European Countries, this may raise serious concerns about non-compliance and a resulting increase in risk of acute rejection or other complications after transplantation procedures. Also, the careful selection of potential recipients in terms of psychological assessment seems to be crucial for success.
There are some important limitations to be discussed regarding the study. First of all this is an on-line survey based study in which we have pre-selected respondents based on our best knowledge of their expertise and up-to-date acquaintance with epidemiological and clinical data from the country. Second, the sources of information on coinfection prevalence varied from personal communication to detailed epidemiological surveillance, thus the weight of the data presented varies significantly across countries.

Irrespective of the above limitations our work shows that the lack of standardized epidemiological data collection on co-infections is a serious obstacle to providing targeted national programs for eliminating $\mathrm{HCV}$ and $\mathrm{HBV}$ infection. In addition, we identified an urgent need to improve access to end-stage liver disease treatment in the Central and Eastern European region and neighboring countries, both for HIV-negative and HIV-positive patients.

\section{Acknowledgments}

The above findings were presented, in part, at the 16th EACS conference in Milano 2017, as a poster presentation. The study has been funded by a research grant issued by the Research Development Foundation in the Hospital for Infectious Diseases.

\section{REFERENCES}

1. Kourtis AP, Bulterys M, Hu DJ, Jamieson DJ. HIVHBV coinfection--a global challenge. N Engl J Med 2012;366(19):1749-52

2. Kim AY, Lauer GM, Ouchi K, Addo MM, Lucas M, Schulze Zur Wiesch J, et al. The magnitude and breadth of hepatitis $\mathrm{C}$ virus-specific CD8+ $\mathrm{T}$ cells depend on absolute CD4+ T-cell count in individuals coinfected with HIV-1. Blood 2005;105(3):1170-8

3. May MT, Ingle SM. Life expectancy of HIV-positive adults: a review. Sex Health. 2011;8(4):526-33

4. Nikolopoulos GK, Paraskevis D, Hatzitheodorou E, Moschidis Z, Sypsa V, Zavitsanos X, et al. Impact of hepatitis $B$ virus infection on the progression of AIDS and mortality in HIV-infected individuals: a cohort study and meta-analysis. Clin Infect Dis. 2009;48(12):176371

5. Weber R, Sabin CA, Friis-Moller N, Reiss P, El-Sadr WM, Kirk O, et al. Liver-related deaths in persons infected with the human immunodeficiency virus: the D:A:D study. Arch Intern Med. 2006;166(15):1632-41

6. Kovari H, Rauch A, Kouyos R, Rougemont M, Cavassini M, Schmid P, et al. Hepatitis C Infection and the Risk of Non-Liver-Related Morbidity and Mortality in HIV-Infected Persons in the Swiss HIV Cohort Study. Clin Infect Dis. 2017;64(4):490-7

7. Peters L. LK, Resnati C., Del Campo S., Leen C., 
Falconer K. for the EuroSIDA Study Group. Uptake of HCV Treatment in HIV/HCV Co-infected Persons across Europe in the Era of Direct-acting Antivirals. Poster No 1954. 2016

8. Kowalska JD, Oprea C, de Witt S, Pozniak A, Gokengin D, Youle M, et al. Euroguidelines in Central and Eastern Europe (ECEE) conference and the Warsaw Declaration - a comprehensive meeting report. HIV Med. 2017;18(5):370-5

9. EMCDDA project group Giraudon I. WL, Hedrich D., Kalamara E., Grffiths P. and Simon R. Hepatitis C among drug users in Europe; Epidemiology, treatment and prevention. 2016

10. Platt L, Easterbrook P, Gower E, McDonald B, Sabin $\mathrm{K}$, McGowan $\mathrm{C}$, et al. Prevalence and burden of $\mathrm{HCV}$ co-infection in people living with HIV: a global systematic review and meta-analysis. Lancet Infect Dis. 2016;16(7):797-808

11. Vickerman P, Martin NK, Roy A, Beattie T, Jarlais $\mathrm{DD}$, Strathdee S, et al. Is the HCV-HIV co-infection prevalence amongst injecting drug users a marker for the level of sexual and injection related HIV transmission? Drug Alcohol Depend. 2013;132(1-2):172-81

12. Soriano V, Mocroft A, Rockstroh J, Ledergerber B, Knysz B, Chaplinskas S, et al. Spontaneous viral clearance, viral load, and genotype distribution of hepatitis $\mathrm{C}$ virus (HCV) in HIV-infected patients with anti-HCV antibodies in Europe. $\mathrm{J}$ Infect Dis. 2008;198(9):1337-44

13. Rockstroh JK, Mocroft A, Soriano V, Tural C, Losso $\mathrm{MH}$, Horban $\mathrm{A}$, et al. Influence of hepatitis $\mathrm{C}$ virus infection on HIV-1 disease progression and response to highly active antiretroviral therapy. J Infect Dis. 2005;192(6):992-1002

14. Soriano V, Sulkowski M, Bergin C, Hatzakis A, Cacoub $\mathrm{P}$, Katlama C, et al. Care of patients with chronic hepatitis $\mathrm{C}$ and HIV co-infection: recommendations from the HIVHCV International Panel. AIDS. 2002;16(6):813-28

15. Barth RE, Huijgen Q, Taljaard J, Hoepelman AI. Hepatitis B/C and HIV in sub-Saharan Africa: an association between highly prevalent infectious diseases. A systematic review and meta-analysis. Int J Infect Dis. 2010;14(12):e1024-31

16. Rao VB, Johari N, du Cros P, Messina J, Ford N, Cooke GS. Hepatitis C seroprevalence and HIV co-infection in sub-Saharan Africa: a systematic review and metaanalysis. Lancet Infect Dis. 2015;15(7):819-24

17. Yan YX, Gao YQ, Sun X, Wang W, Huang XJ, Zhang $\mathrm{T}$, et al. Prevalence of hepatitis $\mathrm{C}$ virus and hepatitis $\mathrm{B}$ virus infections in HIV-positive Chinese patients. Epidemiol Infect. 2011;139(3):354-60

18. Flisiak R, Zarebska-Michaluk D, Janczewska E, Staniaszek A, Gietka A, Mazur W, et al. Treatment of HCV infection in Poland at the beginning of the interferon-free era-the EpiTer-2 study. J Viral Hepat. 2018

19. Soriano V, Barreiro P, Nunez M. Management of chronic hepatitis B and C in HIV-coinfected patients. J Antimicrob Chemother. 2006;57(5):815-8
20. Konopnicki D, Mocroft A, de Wit S, Antunes F, Ledergerber B, Katlama C, et al. Hepatitis B and HIV: prevalence, AIDS progression, response to highly active antiretroviral therapy and increased mortality in the EuroSIDA cohort. AIDS. 2005;19(6):593-601

21. Feng D, Yao T, Cheng YP, Pan MH, Li CX, Wang J, et al. [Prevalence and related factors of $\mathrm{HIV} / \mathrm{HBV}$ coinfection among HIV/AIDS patients]. Zhonghua Liu Xing Bing Xue Za Zhi. 2017;38(12):1624-8

22. Modi AA, Feld JJ. Viral hepatitis and HIV in Africa. AIDS Rev. 2007;9(1):25-39

23. Soriano V, Mocroft A, Peters L, Rockstroh J, Antunes F, Kirkby N, et al. Predictors of hepatitis B virus genotype and viraemia in HIV-infected patients with chronic hepatitis B in Europe. J Antimicrob Chemother. 2010;65(3):548-55

24. Lacombe K, Rockstroh J. HIV and viral hepatitis coinfections: advances and challenges. Gut. 2012;61 Suppl 1:i47-58

25. Kim JH, Psevdos G, Suh J, Sharp VL. Co-infection of hepatitis $\mathrm{B}$ and hepatitis $\mathrm{C}$ virus in human immunodeficiency virus-infected patients in New York City, United States. World J Gastroenterol. 2008;14(43):6689-93

26. Arribas JR, Gonzalez-Garcia JJ, Lorenzo A, Montero D, Ladron de Guevara C, Montes M, et al. Single (B or $\mathrm{C})$, dual (BC or $\mathrm{BD})$ and triple $(\mathrm{BCD})$ viral hepatitis in HIV-infected patients in Madrid, Spain. AIDS. 2005;19(13):1361-5

27. Rong-Rong Y, Xi-En G, Shi-Cheng G, Yong-Xi Z. Interaction of hepatitis $\mathrm{B}$ and $\mathrm{C}$ viruses in patients infected with HIV. J Acquir Immune Defic Syndr. 2008;48(4):505-6

28. Antiretroviral Therapy Cohort C. Causes of death in HIV-1-infected patients treated with antiretroviral therapy, 1996-2006: collaborative analysis of 13 HIV cohort studies. Clin Infect Dis. 2010;50(10):1387-96

29. Stock PG, Roland ME, Carlson L, Freise CE, Roberts JP, Hirose R, et al. Kidney and liver transplantation in human immunodeficiency virus-infected patients: a pilot safety and efficacy study. Transplantation. 2003;76(2):370-5

30. Locke JE, Mehta S, Reed RD, MacLennan P, Massie A, Nellore A, et al. A National Study of Outcomes among HIV-Infected Kidney Transplant Recipients. J Am Soc Nephrol. 2015;26(9):2222-9

31. Locke JE, Durand C, Reed RD, MacLennan PA, Mehta S, Massie A, et al. Long-term Outcomes After Liver Transplantation Among Human Immunodeficiency Virus-Infected Recipients. Transplantation. 2016;100(1):141-6

32. Miro JM, Stock P, Teicher E, Duclos-Vallee JC, Terrault $\mathrm{N}$, Rimola A. Outcome and management of HCV/HIV coinfection pre- and post-liver transplantation. A 2015 update. J Hepatol. 2015;62(3):701-11

33. Ziarkiewicz-Wroblewska B, Suchacz MM, Zieniewicz K, Ciszek M, Oldakowska-Jedynak U, Dudek K, et al. Generalized Posttransplant Kaposi Sarcoma without Mucocutaneous Manifestations in the First Liver Transplantation in an HIV-Positive Patient in Poland: A Case Report and Review of Literature. Ann Transplant. 2016;21:683-8 
34. Council of Europe. European Directorate for the Quality of Medicines \& HealthCare. Newsletter transplant EDQM Vol. 22: :8. 2017

35. Calmy A, van Delden C, Giostra E, Junet C, Rubbia Brandt L, Yerly S, et al. HIV-Positive-to-HIVPositive Liver Transplantation. Am J Transplant. 2016;16(8):2473-8

36. Muller E, Barday Z, Mendelson M, Kahn D. HIV-positive-to-HIV-positive kidney transplantation--results at 3 to 5 years. N Engl J Med. 2015;372(7):613-20

37. Hathorn E, Smit E, Elsharkawy AM, Bramhall SR, Bufton SA, Allan S, et al. HIV-Positive-to-HIVPositive Liver Transplantation. N Engl J Med. 2016;375(18):1807-9

38. Alexiev I, Alexandrova M, Golkocheva-Markova E, Teoharov P, Gancheva A, Kostadinova A, et al. High Rate of Hepatitis B and C Coinfections Among People Living with HIV-1 in Bulgaria: 2010-2014. AIDS Res Hum Retroviruses. 2017;33(3):228-9

39. Vorobjov S, Salekešin M. HIV prevalence and risk behaviours among people who inject drugs in KohtlaJärve, 2016. Tallinn: National Institute for Health Development; 2017. Report in Estonian: http://www.tai. ee/et/terviseandmed/uuringud/download/401

40. Triantos C, Konstantakis C, Tselekouni P, Kalafateli M, Aggeletopoulou I, Manolakopoulos S. Epidemiology of hepatitis C in Greece. World J Gastroenterol. 2016;22(36):8094-102
41. Monitorizarea controlului infecției HIV în Republica Moldova a. https://www.google.com/search?client=safari \&rls $=$ en\&ei $=$ xw06W9_3N8zIwALUpLmwBQ\&q=Moni torizarea + controlului + infectiei $+\mathrm{HIV}+\% 2 \mathrm{C}+$ anul $+2016+\mathrm{i}$ $\mathrm{n}+$ Republica + Moldova\&oq $=$ Monitorizarea + controlului $+\mathrm{i}$ nfectiei + HIV $+\% 2 \mathrm{C}+$ anul $+2016+\mathrm{in}+$ Republica + Moldova \&gs_l=psy-ab.3..0i71k116.0.0.0.31520.0.0.0.0.0.0.0.0..0.0 ...0...1c..64.psy-ab..0.0.0...0.qvu-k3v0XyY available on 02.07.2018. available on 02.07.2018

42. Ruta SM, Matusa RF, Sultana C, Manolescu L, Kozinetz CA, Kline MW, et al. High prevalence of hepatitis B virus markers in Romanian adolescents with human immunodeficiency virus infection. MedGenMed. 2005;7(1):68

43. Skamperle M, Seme K, Lunar MM, Maver PJ, Tomazic J, Vovko TD, et al. Prevalence, genotype distribution, and risk factors for hepatitis $\mathrm{C}$ infection among HIV-infected individuals in Slovenia: a 1986-2013 update. Acta Dermatovenerol Alp Pannonica Adriat. 2014;23(2):25-6

Received: 24.10.2018

Accepted for publication: 13.02.2019

Author for correspondence:

agata.skrzat@op.pl 